\title{
Suppression of MMP-9 by doxycycline in brain arteriovenous malformations
}

\author{
Tomoki Hashimoto*1,4, Melissa M Matsumoto1,4, Jenny F Li1,4, \\ Michael T Lawton ${ }^{2,4}$, William L Young ${ }^{1,3,4}$ and the University of California, \\ San Francisco, BAVM Study Group
}

\begin{abstract}
Address: ${ }^{1}$ Department of Anesthesia and Perioperative Care, University of California, San Francisco, San Francisco, San Francisco, California, USA, ${ }^{2}$ Department of Neurological Surgery, University of California, San Francisco, San Francisco, San Francisco, California, USA, ${ }^{3}$ Department of Neurology, University of California, San Francisco, San Francisco, San Francisco, California, USA and ${ }^{4}$ Center for Cerebrovascular Research, University of California, San Francisco, San Francisco, San Francisco, California, USA

Email: Tomoki Hashimoto* - hashimot@anesthesia.ucsf.edu; Melissa M Matsumoto - matsumotom@anesthesia.ucsf.edu;

Jenny F Li - jennyfli@uclink4.berkeley.edu; Michael T Lawton - lawtonm@neurosurg.ucsf.edu; William L Young - youngw@anesthesia.ucsf.edu * Corresponding author
\end{abstract}

Published: 24 January 2005

BMC Neurology 2005, 5:1 doi:10.1 186/147/-2377-5-I

This article is available from: http://www.biomedcentral.com/I47/-2377/5/I

(c) 2005 Hashimoto et al; licensee BioMed Central Ltd.

This is an Open Access article distributed under the terms of the Creative Commons Attribution License (http://creativecommons.org/licenses/by/2.0), which permits unrestricted use, distribution, and reproduction in any medium, provided the original work is properly cited.
Received: 21 September 2004

Accepted: 24 January 2005

\begin{abstract}
Background: The primary aim of this study is to demonstrate the feasibility of utilizing doxycycline to suppress matrix metalloproteinase-9 (MMP-9) in brain arteriovenous malformations (AVMs).

Methods: Ex-vivo treatment of AVM tissues: Intact AVM tissues were treated with doxycycline for 48 hours. Active and total MMP-9 in the medium were measured. Pilot trial: AVM patients received either doxycycline $(100 \mathrm{mg})$ or placebo twice a day for one week prior to AVM resection. Active and total MMP-9 in BVM tissues were measured.

Results: Ex-vivo treatment of AVM tissues: Doxycycline at 10 and $100 \mu \mathrm{g} / \mathrm{ml}$ significantly decreased MMP-9 levels in AVM tissues ex-vivo (total: control vs 10 vs $100 \mu \mathrm{g} / \mathrm{ml}=100 \pm 6$ vs 60 \pm 16 vs $61 \pm 9 \%$; active: $100 \pm 8$ vs $48 \pm 16$ vs $59 \pm 10 \%)$. Pilot trial: 10 patients received doxycycline, and 4 patients received placebo. There was a trend for both MMP-9 levels to be lower in the doxycycline group than in the placebo group (total: $2.18 \pm 1.94$ vs $3.26 \pm 3.58, P=.50$; active: $0.48 \pm 0.48$ vs $0.95 \pm 1.01 \mathrm{ng} / \mathrm{l} 00 \mu \mathrm{g}$ protein, $\mathrm{P}=.25)$.

Conclusions: A clinically relevant concentration of doxycycline decreased MMP-9 in ex-vivo AVM tissues. Furthermore, there was a trend that oral doxycycline for as short as one week resulted in a decrease in MMP-9 in AVM tissues. Further studies are warranted to justify a clinical trial to test effects of doxycycline on MMP-9 expression in AVM tissues.
\end{abstract}

\section{Background}

Brain arteriovenous malformations (AVM) represent a relatively infrequent but devastating source of neurological morbidity in relatively young adults [1]. Prevention of new or recurrent intracranial hemorrhage (ICH) is the pri- mary rationale for treating AVMs. The optimal management of AVMs is not well defined, and the risk of aggressive surgical therapy can be significantly high. There is a subset of AVM patients that are considered to be inoperable due to the location and size of their lesions [2]. To 
date, there is no clinically available pharmacological treatment of inoperable AVMs to decrease the rate of spontaneous intracranial hemorrhage.

Matrix metalloproteinases (MMPs), a family of proteolytic enzymes, degrade extracellular matrix proteins, cell surface molecules, and other peri-cellular substances [3]. Excessive degradation of the vascular matrix by MMPs may result in the destabilization of the blood vessel that potentially leads to weakening of the vessel wall, passive dilatation, and rupture [4]. Previously, we reported increased levels of MMP-9 activity in AVMs that may result in vascular instability associated with growth and bleeding.

There is an increasing interest in utilizing MMP inhibitors in treating vascular diseases including abdominal aortic aneurysms. Doxycycline is a clinically available antibiotic agent that possesses non-specific inhibitory effects on various MMPs, and for years it has had a well-established safety record in treating infectious diseases.

The primary aim of this study is to demonstrate the feasibility of utilizing doxycycline as an MMP inhibitor to decrease MMP-9 activity in AVMs and potentially decrease the rate of spontaneous hemorrhage. This exploratory investigation supports the concept that further studies be conducted to document the ability of tetracycline and its derivatives to decrease MMP-9 levels in AVM nidal tissue. Such a demonstration could provide a firm rationale for proceeding with clinical trials to test the hypothesis that tetracycline and its derivatives are useful to decrease the rate of spontaneous hemorrhage from AVMs in otherwise untreatable patients or in those awaiting interventional treatment.

First, we demonstrate that doxycycline can decrease MMP9 activity in cultured AVM tissues as a proof of the concept. Further, we present results from a pilot clinical study demonstrating effects of oral doxycycline treatment on MMP-9 expression in AVM tissues.

\section{Methods}

\section{Ex-vivo treatment of cultured AVM tissues}

After institutional review and informed consent, we obtained AVM specimens after microsurgical resection. AVM nidus was dissected away from any adjacent brain tissue in the operating room and a representative portion of nidus tissue was used for ex-vivo treatment. Ex-vivo culture of AVM tissue was performed using previously described method with modifications [5].

AVM tissues were minced into 1-2 mm fragments and vigorously washed with phosphate buffered saline (PBS). Blood cells dissociated from the tissues were removed by filtration. AVM tissue fragments were placed onto cell culture inserts and immersed in cell culture medium. During the first 24 hours, AVM tissues were incubated in DME H21 medium containing $10 \%$ fetal bovine serum (FBS) to aid in tissue recovery. Following this recovery period, tissue debris and dissociated cells were removed, and AVM tissues were incubated in DME $\mathrm{H}-21$ medium containing $1 \%$ FBS for 4 hours. The tissue fragments were equally divided into 12-24 wells. Then AVM tissues were incubated in the medium containing PBS (control) or doxycycline $(1,5,10$ and $100 \mu \mathrm{g} / \mathrm{ml})$. Each group included 3-5 wells. Size of the tissues dictated a number of treatment groups in each specimen.

Medium from each well was collected after 48 hours. Active and total MMP-9 were measured using substrate zymography. Medium was mixed with SDS sample buffer (Invitrogen, Carlsbad, CA, U.S.A.) and separated under non-reducing conditions in a $10 \%$ zymogram gel (Invitrogen) containing $0.1 \%$ gelatin incorporated as a substrate. Recombinant MMP-2 and MMP-9 proteins (R\&D systems) were used as positive controls. After running, the gel was incubated with renaturing buffer (Invitrogen). The gel was then incubated with developing buffer (Invitrogen) overnight at $37^{\circ} \mathrm{C}$. The gel was then stained with colloidal blue stain (Invitrogen). Proteolytic bands in the zymogram gels were quantified using Image J Software (NIH).

Tissue viability was assessed by measuring the amount of LDH (lactate dehydrogenase) released in the medium according to the manufacturer's instructions (Roche, Penzburg, Germany). Some of the tissue fragments were embedded in paraffin for histological assessment.

\section{Pilot clinical study}

Fourteen AVM patients received either 100 mg of doxycycline or placebo twice a day for one week, prior to elective AVM resection. During the AVM resection, AVM tissues were collected, and nidus tissues were frozen in liquid nitrogen. Frozen tissues were stored at $-80^{\circ} \mathrm{C}$ until analysis. Clinical data were collected as previously described [6].

The specimens were homogenized and insoluble materials were removed by centrifugation at $3000 \mathrm{rpm}$ for 5 minutes. We used total MMP-9 ELISA kit (R\&D) and active MMP-9 ELISA kit (Amersham).

\section{Statistical analysis}

Data are presented as mean \pm standard deviation. The data for total MMP-9 and active MMP-9 from ex-vivo AVM tissues are presented as a relative expression with control brain samples as $100 \%$. We used ANOVA for comparison, and statistical significance was taken at $P<.05$. 


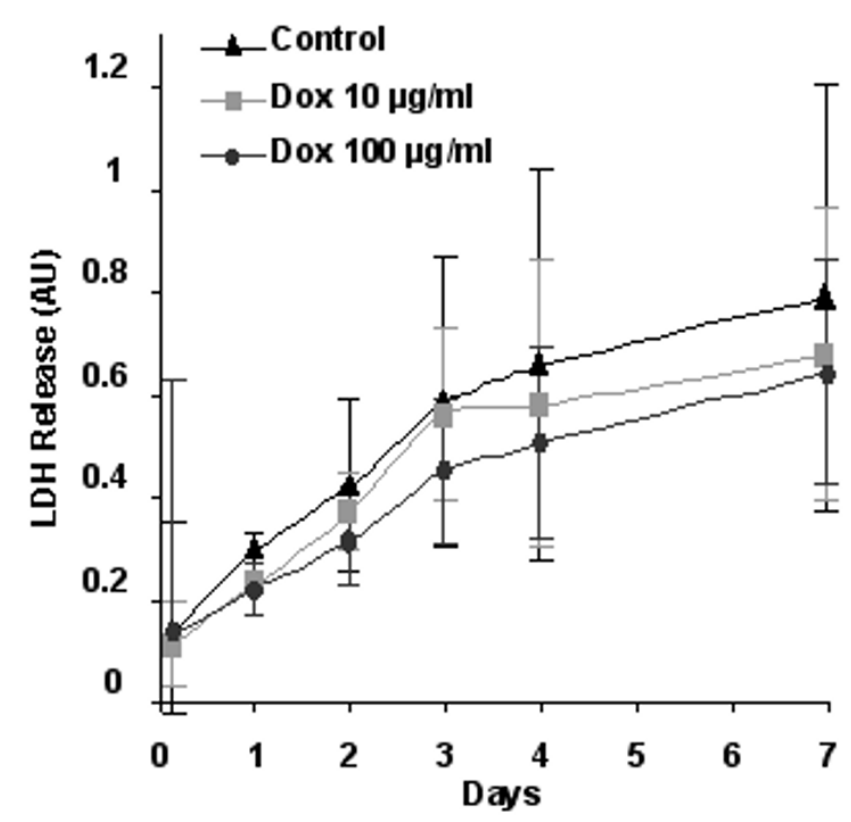

Figure I

Tissue viability assessed by LDH (lactate dehydrogenase) release. There was a gradual increase in $\mathrm{LDH}$ release (mean \pm SD) over the course of 8 days, indicating continuous cellular death and a gradual decrease in tissue viability. However, there was no difference among different treatment groups.

\section{Results}

\section{Ex-vivo treatment of cultured AVM tissues}

We collected two AVM tissues for ex-vivo treatment with doxycycline. These patients were not enrolled in the pilot clinical study.

\section{AVM-I}

AVM tissue-I was collected from a 28 y.o. patient with a 29 mm AVM (Spetzler-Martin score 3). The patient had an AVM hemorrhage 236 days prior to the AVM resection. The patient did not receive embolization treatment or radiosurgery. AVM tissue-I was divided into 9 wells and treated with 0,10 , and $100 \mathrm{ng} / \mathrm{ml}$ of doxycycline (3 wells for each). Two doxycycline doses were selected to test (1) whether an average doxycycline concentration $(10 \mathrm{ng} / \mathrm{ml})$ achieved by standard clinical treatment has any effects on MMP-9 in AVM tissue, and (2) whether a high concentration of doxycycline $(100 \mathrm{ng} / \mathrm{ml})$ has any effects of viability of AVM tissues in vitro.

There was a gradual increase in $\mathrm{LDH}$ release over the course of 8 days, indicating continuous cellular death and a gradual decrease in tissue viability (Figure 1). However, there was no difference among different treatment groups. To avoid effects from ongoing cellular death and to ensure tissue viability during the treatment, we chose the first 48 hours to assess the effects of doxycycline on MMP-9 levels in AVM tissues.

Tissue integrity was further assessed by examining H\&E staining of ex-vivo cultured tissues (Figure 2). On day 0 (before the treatment), although cutting and mincing of the AVM tissues had caused minor tissue injury and distortion, a majority of blood vessels were intact and viable. On day 2 (after 48 hours of treatment), blood vessels were still intact and viable, and there was no apparent necrosis or hyalinization of the tissues. However, on day 7, a major part of the tissues, especially tissues surrounding blood vessels were anuclear and hyalinized, indicating that tissues were not intact or viable anymore.

Doxycycline $10 \mu \mathrm{g} / \mathrm{ml}$ and $100 \mu \mathrm{g} / \mathrm{ml}$ significantly decreased active MMP-9 (control vs doxycycline $10 \mu \mathrm{g} / \mathrm{ml}$ : $100 \pm 8$ vs $48 \pm 16 \%$-control, $\mathrm{P}<.05$; control vs doxycycline $100 \mu \mathrm{g} / \mathrm{ml}: 100 \pm 8$ vs $59 \pm 10 \%$-control, $\mathrm{P}<.05$ ) (Figure 4A). In addition, there was a significant reduction of total MMP-9 by doxycycline at 10 and $100 \mu \mathrm{g} / \mathrm{ml}$ (control vs doxycycline $10 \mu \mathrm{g} / \mathrm{ml}$ : $100 \pm 6$ vs $60 \pm 16 \%$-control, $\mathrm{P}<.05$; control vs doxycycline $100 \mu \mathrm{g} / \mathrm{ml}: 100 \pm 6$ vs $61 \pm$ $9 \%$-control, $\mathrm{P}<.05$ ). (Figure $4 \mathrm{~B}$ ) There was no difference in active MMP-9 and total MMP-9 between doxycycline at $10 \mu \mathrm{g} / \mathrm{ml}$ and $100 \mu \mathrm{g} / \mathrm{ml}$. A representative zymogram is shown in Figure 3.

\section{AVM-II}

AVM tissue-II was collected from a 63 y.o. patient with a $22 \mathrm{~mm}$ AVM (Spetzler-Martin score 2). The patients had a history of AVM hemorrhage 167 days prior to the AVM resection. The patient received an embolization treatment 1 day before the AVM resection. The patient did not receive radiosurgery.

Using this tissue, we aimed to study effects of doxycycline at more clinically relevant concentrations of doxycycline $(1-10 \mu \mathrm{g} / \mathrm{ml})$. Therefore, AVM tissue-II was treated with 0 , 1,5 , and $10 \mu \mathrm{g} / \mathrm{ml}$ of doxycycline for 48 hours. Since the results from AVM tissue-I showed a relatively wide variation in MMP-9 levels in each well among the same treatment group, we increased wells per treatment group from 3 to 4 .

There was no difference in tissue viability indicated by LDH release among different treatment groups at 48 hours (data not shown). Similar to the AVM-I, doxycycline $10 \mu \mathrm{g} / \mathrm{ml}$ significantly decreased active and total MMP-9 (active MMP-9: control vs doxycycline $10 \mu \mathrm{g} / \mathrm{ml}$ : $100 \pm 54$ vs $43 \pm 15 \%$-control, $\mathrm{P}<.05$; total MMP-9: control vs doxycycline $10 \mu \mathrm{g} / \mathrm{ml}: 100 \pm 41$ vs $59 \pm 21 \%$-con- 


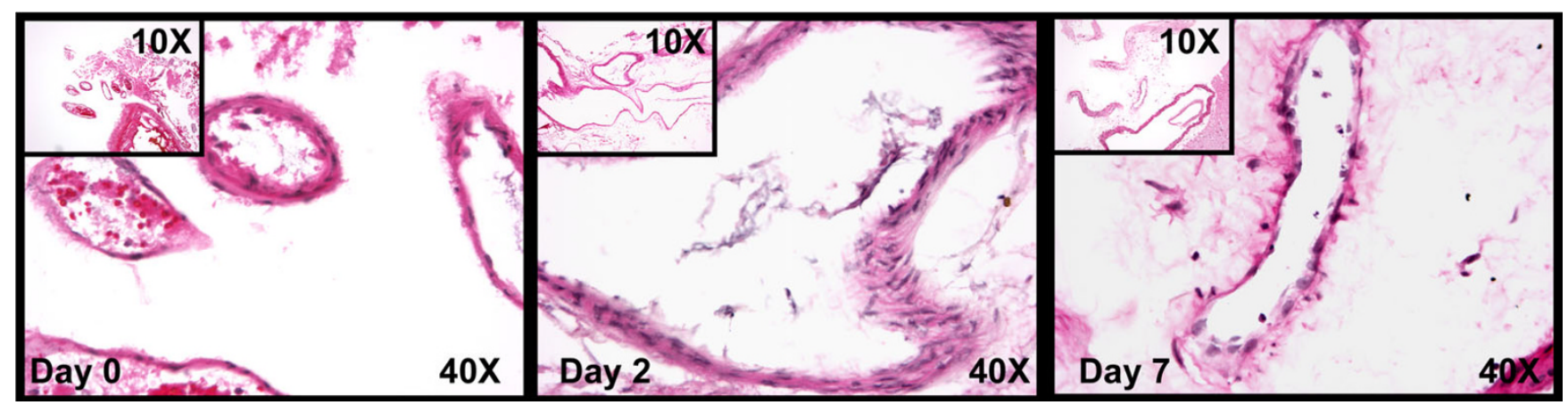

Figure 2

H\&E staining of ex-vivo cultured AVM tissues. On day 0 (before the treatment), although cutting and mincing of the AVM tissues appeared to cause minor tissue injury and distortion, a majority of blood vessels was intact and viable. On day 2 (after 48 hours of treatment), blood vessels were still intact and viable, and there was no apparent necrosis or hyalinization of the tissues. However, on day 7, a major part of the tissues, especially tissues surrounding blood vessels were anuclear and hyalinized, indicating that tissues were not intact or viable anymore.

trol, $\mathrm{P}<.05)$ (Figure 4C \&4D). In addition, there was a trend for doxycycline 1 and $5 \mu \mathrm{g} / \mathrm{ml}$ to decrease active and total MMP-9.

\section{Pilot clinical trial}

14 AVM patients were enrolled. The trial was originally started as a double blinded randomized trial, and 9 patients were randomized. In an effort to improve recruitment for this feasibility study, we converted to an open label drug design.

10 patients received doxycycline, and 4 patients received placebo. Clinical data are shown in Table 1. Subjects were informed regarding possible side effects including gastrointestinal symptoms, cutaneous photosensitivity, skin pigmentation, teeth discoloration, and vestibular side effects. To monitor compliance and possible side effects, study subjects were interviewed by phone three times during one-week treatment period. One patient had nausea that was relieved by taking food with the drug. Other side effects were not noted.

There was a trend for both total MMP-9 and active MMP9 levels to be lower in the doxycycline group than in the placebo group (total MMP-9: $2.18 \pm 1.94$ vs $3.26 \pm 3.58$ ng/100 $\mu$ g protein, $\mathrm{P}=.50$; active MMP-9: $0.48 \pm 0.48$ vs $0.95 \pm 1.01 \mathrm{ng} / 100 \mu \mathrm{g}$ protein, $\mathrm{P}=.25$ ) (Figure 5).

\section{Discussion}

In this study, we demonstrated the feasibility of doxycycline, a tetracycline derivative, to decrease MMP-9 activity in AVM tissues. First, we demonstrated that a clinically relevant concentration of doxycycline decreased MMP-9 without affecting tissue viability in ex-vivo AVM tissues.
Second, there was a trend that oral administration of doxycycline for as short as one week in AVM patients resulted in a decrease in MMP-9 at the target site - in the AVM nidus. By decreasing MMP-9 activity in AVM tissues, doxycycline may be able to restore the structural stability of AVM blood vessels and modify the clinical course of AVMs. Our data will provide the basis to conduct a clinical study to assess effects of tetracycline derivative treatment on the prevention of hemorrhage from AVMs.

MMP-9 is a major enzyme that degrades the vascular extracellular matrix and has been implicated in a number of vascular diseases that involve abnormal angiogenesis and vascular remodeling [7]. MMPs are reported to be increased in cerebral aneurysms, atherosclerotic carotid plaque, and abdominal aortic aneurysm [8-10]. MMPs are emerging as a potentially new therapeutic target to treat vascular diseases. It has been proposed that pharmacological inhibition of MMPs may stabilize the unstable blood vessels and prevent complications such as vessel rupture [7]. In patients with abdominal aortic aneurysm, doxycycline treatment for one week prior to the repair surgery resulted in decreased MMP-9 and MMP-2 in the wall of the aneurysms [10]. Similar results have been reported in patients with atherosclerotic carotid plaques who received doxycycline for 2-8 weeks [11].

Our data using ex-vivo AVM tissues showed that abnormally high levels of MMP-9 expression in AVM tissues could be reduced by a clinically relevant concentration of doxycycline (i.e. $1-10 \mu \mathrm{g} / \mathrm{ml}$ ). In patients with abdominal aortic aneurysm, doxycycline treatment at a conventional dose, $200 \mathrm{mg} /$ day, resulted in a mean plasma concentration of doxycycline at $4.6 \mu \mathrm{g} / \mathrm{ml}$ with a range of 1.3 to 14.4 


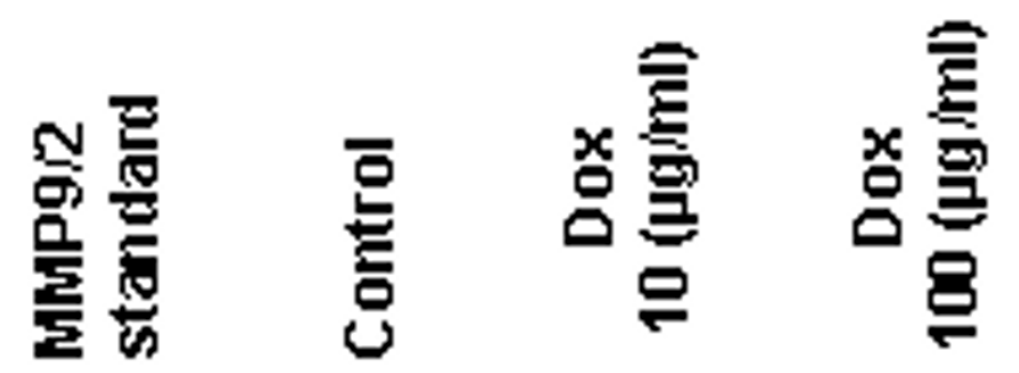

\section{Pro MMP-9}

\section{Active MMP-9}

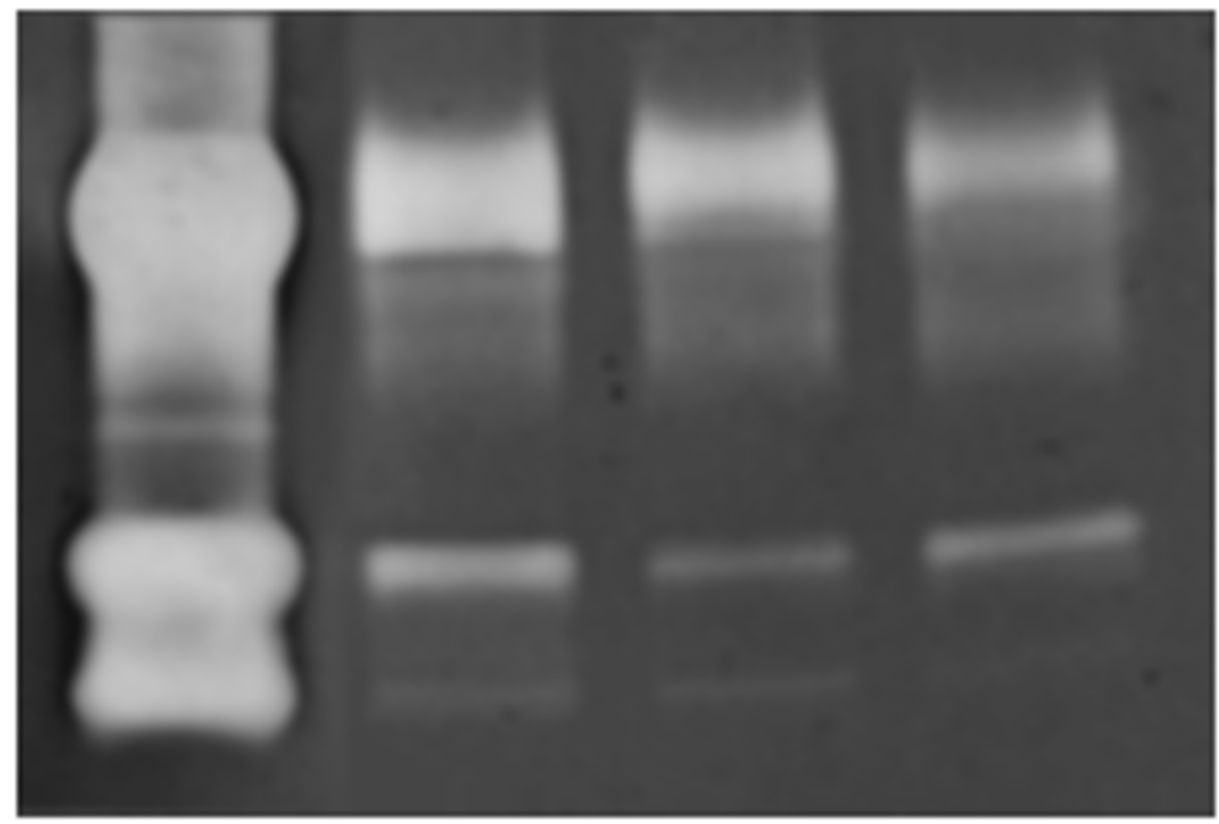

\section{Figure 3}

Representative zymogram showing MMP-9 and MMP-2 standard, control AVM tissues, AVM tissues treated with $10 \mu \mathrm{g} / \mathrm{ml}$ doxycycline, and AVM tissues treated with $100 \mu \mathrm{g} / \mathrm{ml}$ doxycycline. In AVM tissues, there were proteolytic bands corresponding to pro-MMP-9 $(\approx 97 \mathrm{kDa})$ and active-MMP-9 ( $\approx 88 \mathrm{kDa})$.

$\mu \mathrm{g} / \mathrm{ml}$ in humans, and there was a corresponding reduction in plasma MMP-9 levels [12]. Similar plasma levels of doxycycline in mice successfully inhibited growth of experimental abdominal aortic aneurysms [13]. We were able to show that doxycycline at $10 \mu \mathrm{g} / \mathrm{ml}$ for as short as 48 hours can reduce MMP-9 expression in AVM tissues. A longer duration of treatment often used in clinical settings may result in a more pronounced reduction in MMP-9 expression in AVM tissues.

One of the limitations of the ex-vivo study was the relatively short duration of doxycycline treatment. We chose 48 hours treatment to ensure tissue viability and integrity. Although we chose the doxycycline concentrations based on plasma doxycycline levels achieved by a commonly used therapeutic regimen, it is possible that tissue levels of doxycycline might be significantly lower than those of plasma. Furthermore, functional consequences of the reduction of MMP-9 in AVMs need to be examined in animal models or clinical studies. However, at the present time, there is no animal model that approximates recurrent intracranial hemorrhage from AVMs. There are models that can mimic certain aspects of the AVM phenotype. Hyperstimulation of mouse brain with VEGF using adenoviral transduction causes an increase in capillary density, increased MMP-9 activity, and may, in the appropriate genetic background, result in small vascular malformations [14]. Doxycycline can reduce capillary density and MMP-9 activity in this model [15].

Doxycycline has been shown in other human vascular diseases to reduce MMP levels. For example, Axisa et al. treated patients undergoing carotid endarterectomy with doxycycline or placebo for 2-8 weeks. Although MMP-1, 
AYM-I

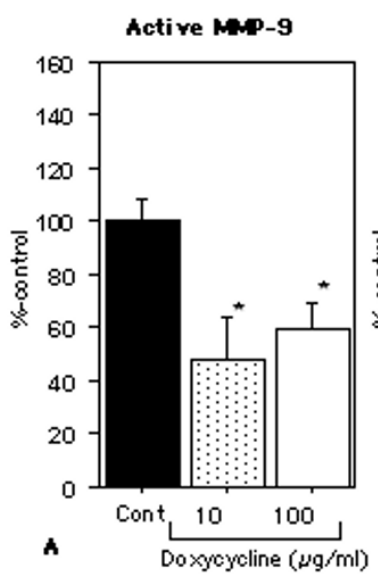

Total MAp-9

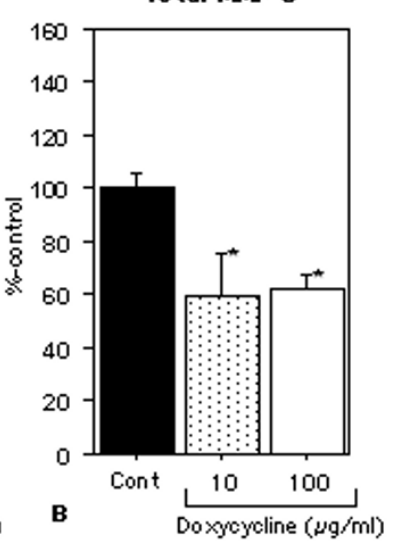

Actire MP-9

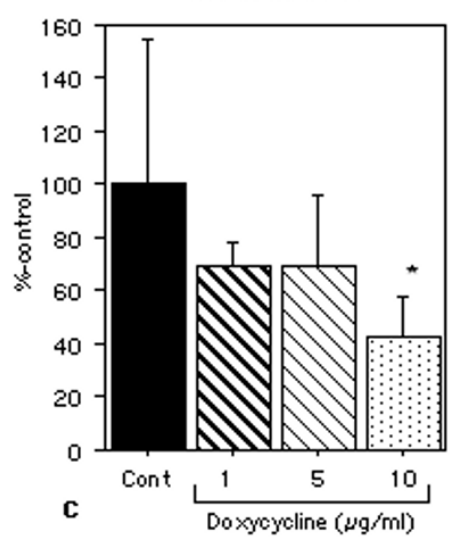

AYMIII

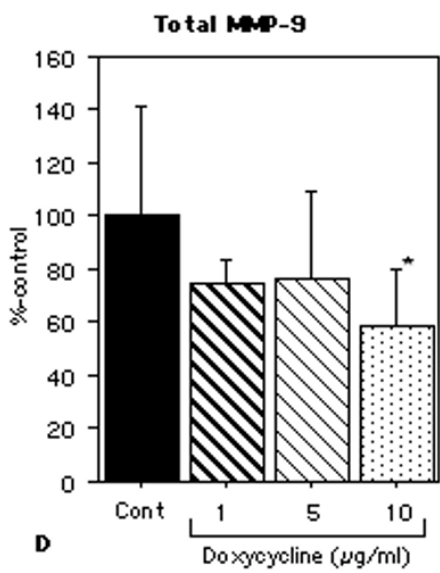

Figure 4

Active and total MMP-9 levels after 48 hours of ex-vivo doxycycline treatment. AVM-I: Doxycycline $10 \mu g / \mathrm{ml}$ and $100 \mu \mathrm{g} / \mathrm{ml}$ significantly decreased active MMP-9 There was a significant reduction of total MMP-9 by doxycycline at 10 and 100 $\mu \mathrm{g} / \mathrm{ml}$ There was no difference in active MMP-9 and total MMP-9 between doxycycline at $10 \mu \mathrm{g} / \mathrm{ml}$ and $100 \mu \mathrm{g} / \mathrm{ml}$. AVM-II: Doxycycline $10 \mu \mathrm{g} / \mathrm{ml}$ significantly decreased active and total MMP-9. There was a trend for doxycycline I and $5 \mu \mathrm{g} / \mathrm{ml}$ to decrease active and total MMP-9. (mean \pm SD)

Table I: Characteristics of AVM patients enrolled in a pilot clinical study to test effects of oral doxycycline treatment on MMP-9 in AVM lesions.

\begin{tabular}{|c|c|c|c|c|c|c|c|}
\hline Group & Age & Gender & S-M score* & AVM size** & Draining veins & $\begin{array}{l}\text { History of } \\
\text { hemorrhage }\end{array}$ & $\begin{array}{c}\text { Number of embolization } \\
\text { treatments }\end{array}$ \\
\hline Dox & 50 & $M$ & 4 & 38 & Superficial \& Deep & No & I \\
\hline Dox & 48 & $\mathrm{~F}$ & 4 & 30 & Deep & Yes & 0 \\
\hline Dox & 52 & M & 4 & 42 & Superficial \& Deep & Yes & 2 \\
\hline Dox & 43 & $M$ & 3 & 29 & Superficial \& Deep & No & 1 \\
\hline Dox & 23 & $M$ & 4 & 34 & Superficial \& Deep & No & 2 \\
\hline Dox & 28 & $M$ & 4 & 40 & Superficial & Yes & 2 \\
\hline Dox & 56 & $M$ & 2 & 10 & Superficial & No & \\
\hline Dox & 41 & $\mathrm{~F}$ & 3 & 30 & Superficial & No & 1 \\
\hline Dox & 62 & $M$ & 2 & 41 & Superficial & No & I \\
\hline Dox & 42 & M & 2 & 2 & Superficial & Yes & 0 \\
\hline Placebo & 53 & $M$ & 2 & 28 & Superficial \& Deep & No & I \\
\hline Placebo & 17 & M & 1 & 18 & Superficial & No & 1 \\
\hline Placebo & 48 & $\mathrm{~F}$ & 2 & 13 & Deep & No & 0 \\
\hline Placebo & 22 & $M$ & 3 & 19 & Deep & Yes & 0 \\
\hline
\end{tabular}

* Spetzler-Martin score (I5), **AVM maximum diameter (10). Dox = doxycycline

MMP-3, and MMP-9 were reported to be increased, only MMP-1 had a statistically significant reduction by doxycycline; there was a trend for MMP-9 to be decreased by
$22 \%$. Baxter et al. used a much longer treatment period, 6 months, in patients with abdominal aortic aneurysm. They reported a gradual reduction of plasma MMP-9 lev- 

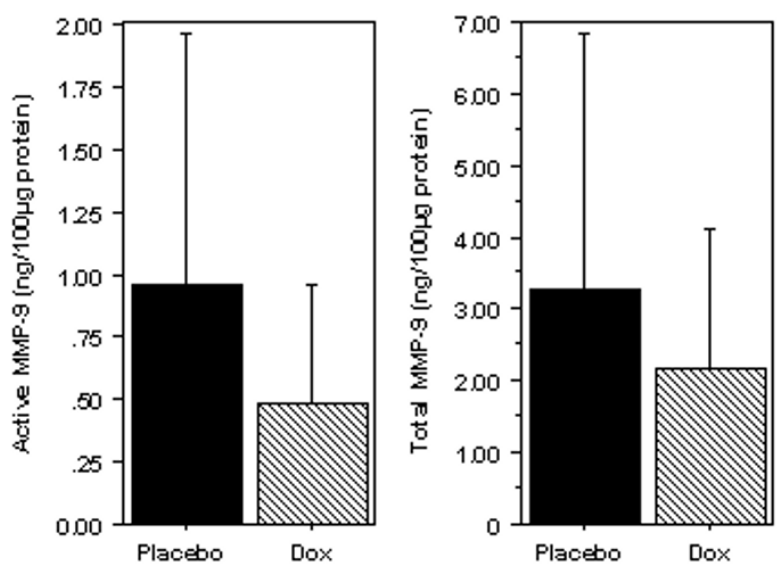

\section{Figure 5}

Effects of oral doxycycline treatment on MMP-9 in AVM tissues. There was a trend for both total MMP-9 and active MMP-9 levels to be lower in the doxycycline group than in the placebo group. (mean \pm SD)

els by oral doxycycline over 6 month treatment period (baseline vs 3 months vs 6 months: $119 \pm 38$ vs $84 \pm 33$ vs $66 \pm 24 \mathrm{ng} / \mathrm{ml})[12]$.

To further explore the feasibility of a clinical application of doxycycline in modifying the clinical course of AVMs, we conducted a pilot clinical trial. This trial was primarily designed to test the effects of a short-term treatment with oral doxycycline on the expression of MMP-9 in AVM tissues. Despite the small sample size and short duration of treatment used in this study, there was a clear trend for one week of oral doxycycline treatment prior to surgical resection to reduce expression of both active and total MMP-9 in AVM tissues. These results indicate the feasibility of oral treatment with tetracycline derivatives in reducing MMP-9 activity in AVM tissues.

Despite a large difference in the mean values of MMP levels in our pilot data, variance of MMP levels was high. Accordingly, a sample size of 46 in each group would be needed to demonstrate a difference in active MMP-9, assuming an alpha of 0.05 and power of $80 \%$. However, variance may be reduced by utilizing a longer duration of treatment, as suggested by studies in other diseases $[11,12]$. A clinical study with a modestly larger sample size and longer treatment duration should suffice to verify effects of oral doxycycline on reducing MMP-9 activity in AVMs.
There are some further considerations that may account for our high variance that could be avoided in future studies. Surgical AVM tissues consist mainly from nidal tissues, but they may contain intervening astroglial or neuronal tissues that may not express angiogenic factors to the same extent as nidal tissue. Histological examination of each AVM tissue fragments to confirm a predominance of nidal tissues may yield more homogenous tissue and decrease variability in MMP-9 levels. Some of the homogenized samples underwent a several "thaw-freeze" processes during the preliminary phase of the experiments, which may have increased variability in MMP-9 levels. Embolization treatment may affect production and activation of MMPs. Our previous study, however, showed no association between MMP-9 and embolization treatment in 37 AVM patients [16]. Based on the experience from this pilot study, future studies can be performed in a more standardized fashion to decrease tissue-to-tissue variability.

We used different methods to measure MMP-9 in the medium collected from ex-vivo AVM tissues and homogenized AVM tissues from the pilot clinical trial. We chose zymography, a gel based method detecting enzymatic activity of MMPs, for ex-vivo AVM tissues, because the medium volume that can be used for MMP-9 assay was extremely limited, and our preliminary experiments showed higher sensitivity of zymography compared to ELISA. One of the disadvantages of using zymography is that "gel-to-gel" variability in sensitivity makes it difficult to combine the data obtained from multiple gels. On the other hand, ELISA method allows researchers to assay approximately 40 samples at a time when duplicates are used. In addition, establishing a standard curve, ELISA method can express MMP-9 expression values by the absolute unit such as $\mu \mathrm{g} / \mathrm{ml}$ or $\mathrm{ng} / 100 \mu \mathrm{g}$ protein. Therefore, for the clinical pilot trial, in order to quantitatively compare MMP-9 expression among a large number of samples originally planned, we used ELISA to MMP-9 expression.

\section{Conclusions}

In summary, results suggest that doxycycline may have a therapeutic potential to reduce MMP-9 activity in AVM tissues and stabilize blood vessels that are prone to rupture. Our findings may provide a basis for a larger clinical trial to study effects of tetracycline derivatives in preventing AVM hemorrhage.

\section{Competing interests}

The author(s) declare that they have no competing interests. 


\section{Authors' contributions}

$\mathrm{TH}$, a corresponding author, participated in all aspects of the study and manuscript preparation. MMM participated in study design, experiments, analysis, interpretation of data, and manuscript preparation. JFL participated in experiments, analysis and interpretation of data. MTL participated in study design, analysis, interpretation of data, and manuscript preparation. WLY participated in study design, analysis, interpretation of data, and manuscript preparation.

\section{Acknowledgments}

The authors wish to thank Broderick Belenson and Carroll Schreibman for assistance in preparation of the manuscript; Nancy Quinnine, RN and Manju Chopra, MD, for technical assistance; and the members of Center for Cerebrovascular Research and the UCSF AVM Study Project for their continued support.

Portions of this work were supported by NIH grants ROI-277I 3 and K24NS0209I (WLY), POI-NS44I55 (WLY, TH), and American Heart Association Beginning Grant-in-Aid (TH).

\section{References}

I. Arteriovenous malformations of the brain in adults. $N$ Engl J Med 1999, 340:1812-1818.

2. Han PP, Ponce FA, Spetzler RF: Intention-to-treat analysis of Spetzler-Martin grades IV and $V$ arteriovenous malformations: natural history and treatment paradigm. J Neurosurg 2003, 98:3-7.

3. Sternlicht M, Bergers G: Matrix metalloproteinases as emerging targets in anticancer therapy: status and prospects. Emerging Therapeutic Targets 2000, 4:609-633.

4. Hashimoto T, Lawton MT, Wen G, Yang GY, Chaly T Jr, Stewart CL, Dressman HK, Barbaro NM, Marchuk DA, Young WL: Gene Microarray Analysis of Human Brain Arteriovenous Malformations. Neurosurgery 2004, 54:410-425.

5. Fjellbirkeland L, Cambier S, Broaddus VC, Hill A, Brunetta P, Dolganov G, Jablons D, Nishimura SL: Integrin alphavbeta8-mediated activation of transforming growth factor-beta inhibits human airway epithelial proliferation in intact bronchial tissue. Am J Pathol 2003, I 63:533-542.

6. Joint Writing Group of the Technology Assessment Committee, Joint Section on Cerebrovascular Neurosurgery, a section of American Association of Neurological Surgeons and Congress of Neurological Surgeons, and Section of Stroke and the Section of Interventional Neurology of the American Academy of Neurology: Reporting terminology for brain arteriovenous malformation clinical and radiographic features for use in clinical trials. Stroke 200I, 32:|430-1442.

7. Rosenberg GA: Growth and bleeding in BAVM: another role for MMPs. Stroke 2003, 34:925-93I.

8. Galis ZS, Sukhova GK, Lark MW, Libby P: Increased expression of matrix metalloproteinases and matrix degrading activity in vulnerable regions of human atherosclerotic plaques. J Clin Invest 1994, 94:2493-2503.

9. Kim SC, Singh M, Huang J, Prestigiacomo CJ, Winfree CJ, Solomon RA, Connolly ES Jr: Matrix metalloproteinase-9 in cerebral aneurysms. Neurosurgery 1997, 4 I:642-666. discussion 646-647

10. Curci JA, Mao D, Bohner DG, Allen BT, Rubin BG, Reilly JM, Sicard GA, Thompson RW: Preoperative treatment with doxycycline reduces aortic wall expression and activation of matrix metalloproteinases in patients with abdominal aortic aneurysms. J Vasc Surg 2000, 3 I:325-342.

II. Axisa B, Loftus IM, Naylor AR, Goodall S, Jones L, Bell PR, Thompson $M M$ : Prospective, randomized, double-blind trial investigating the effect of doxycycline on matrix metalloproteinase expression within atherosclerotic carotid plaques. Stroke 2002, 33:2858-2864.
12. Baxter BT, Pearce WH, Waltke EA, Littooy FN, Hallett JW Jr, Kent KC, Upchurch GR Jr, Chaikof EL, Mills JL, Fleckten B, et al.: Prolonged administration of doxycycline in patients with small asymptomatic abdominal aortic aneurysms: Report of a prospective (Phase II) multicenter study. J Vasc Surg 2002, 36: I- I 2.

13. Prall AK, Longo GM, Mayhan WG, Waltke EA, Fleckten B, Thompson RW, Baxter BT: Doxycycline in patients with abdominal aortic aneurysms and in mice: comparison of serum levels and effect on aneurysm growth in mice. J Vasc Surg 2002, 35:923-929.

14. Xu B, Wu YQ, Huey M, Arthur HM, Marchuk DA, Hashimoto T, Young WL, Yang GY: Vascular Endothelial Growth Factor Induces Abnormal Microvasculature in the Endoglin Heterozygous Mouse Brain. J Cereb Blood Flow Metab 2004, 24:237-244.

15. Lee CZ, Xu B, Hashimoto T, McCulloch CE, Yang GY, Young WL: Doxycycline Suppresses Cerebral Matrix Metalloproteinase9 and Angiogenesis Induced by Focal Hyperstimulation of Vascular Endothelial Growth Factor in a Mouse Model. Stroke 2004, 35:1715-1719.

16. Hashimoto T, Wen G, Lawton MT, Boudreau NJ, Bollen AW, Yang GY, Barbaro NM, Higashida RT, Dowd CF, Halbach VV, Young WL: Abnormal expression of matrix metalloproteinases and tissue inhibitors of metalloproteinases in brain arteriovenous malformations. Stroke 2003, 34:925-931.

\section{Pre-publication history}

The pre-publication history for this paper can be accessed here:

http://www.biomedcentral.com/1471-2377/5/1/prepub

Publish with Bio Med Central and every scientist can read your work free of charge

"BioMed Central will be the most significant development for disseminating the results of biomedical research in our lifetime. "

Sir Paul Nurse, Cancer Research UK

Your research papers will be:

- available free of charge to the entire biomedical community

- peer reviewed and published immediately upon acceptance

- cited in PubMed and archived on PubMed Central

- yours - you keep the copyright

Submit your manuscript here:

http://www.biomedcentral.com/info/publishing_adv.asp

BioMedcentral 